This is an electronic reprint of the original article. This reprint may differ from the original in pagination and typographic detail.

Author(s): Virtanen, Anne; Tynjälä, Päivi; Collin, Kaija

Title: Characteristics of workplace learning among Finnish vocational students

Year: $\quad 2009$

Version:

Please cite the original version:

Virtanen, A., Tynjälä, P., \& Collin, K. (2009). Characteristics of workplace learning among Finnish vocational students. Vocations and Learning, 2(3), 153-175.

https://doi.org/10.1007/s12186-009-9022-9

All material supplied via JYX is protected by copyright and other intellectual property rights, and duplication or sale of all or part of any of the repository collections is not permitted, except that material may be duplicated by you for your research use or educational purposes in electronic or print form. You must obtain permission for any other use. Electronic or print copies may not be offered, whether for sale or otherwise to anyone who is not an authorised user. 


\section{Characteristics of workplace learning among Finnish vocational students}

\section{Anne Virtanen}

Finnish Institute for Educational Research

P.O. Box 35

40014 University of Jyväskylä

Finland

Tel. +358142603218

Email: anne.m.virtanen@jyu.fi

Anne Virtanen, MEd, PhD student, works as a researcher at the Finnish Institute for Educational Research of the University of Jyväskylä, Finland. In her forthcoming doctoral thesis she will study students' learning at work in the Finnish Vocational Education and Training sector.

\section{Päivi Tynjälä}

Finnish Institute for Educational Research

P.O. Box 35

40014 University of Jyväskylä

Finland

Tel. +358 142603219

Email: paivi.tynjala@jyu.fi

Päivi Tynjälä, $\mathrm{PhD}$, is a professor at the Finnish Institute for Educational Research of the University of Jyväskylä, Finland. Se is specialised in research on learning and the development of expertise at the interface between education and work.

\section{Kaija Collin}

Department of Educational Sciences

P.O. Box 35

40014 University of Jyväskylä

Finland

Tel. +358142601675

Email: kaija.m.collin@jyu.fi

Kaija Collin is senior researcher at the Department of Educational Sciences, University of Jyväskylä, Finland. Her current research focuses on the intermediate processes of individual and social learning at work and on the innovative learning spaces created within workplaces. She is especially interested in industrial design and surgical work as learning contexts.

Keywords: workplace learning, vocational students, vocational education and training (VET), Finland 


\title{
CHARACTERISTICS OF WORKPLACE LEARNING AMONG FINNISH VOCATIONAL STUDENTS
}

\begin{abstract}
In Finnish VET, students' work experience is explicitly defined as workplace learning instead of the practice of already learnt skills. Therefore, vocational students' learning periods in the workplace are goal-oriented, guided and assessed. This paper examines the characteristics of students' workplace learning and compares them with the characteristics of employees' workplace learning. The data were collected with an Internet questionnaire from finalyear vocational students $(\mathrm{N}=3106)$. In total, 1603 students $(52 \%)$ answered the questionnaire. The data were analysed using quantitative methods. The results indicate that features typical of employees' workplace learning can also be found in student learning as well. However, VETrelated workplace learning has a number of characteristics that have not been brought to light in research on employees' workplace learning thus far. We suggest that in developing educational practices it would be useful to draw on some of the features of workplace learning such as the use of collaboration and shared practices; conversely for workplace practices it would be useful to draw on some of the features of educational practices. For example, by utilising the structures of students' workplace learning system presented in this study, learning at work could be transformed towards more goal-directed, guided and assessed activity.
\end{abstract}

\section{Introduction}

Changes in working life involving new qualifications and new forms of training have influenced the development of formal vocational education in many countries (e.g. Streumer \& Kho 2006). This has also happened in Finland where vocational education and training (VET) system was substantially reformed at the turn of the millennium. One of the biggest changes was the introduction of workplace learning periods as a part of all vocational qualifications. This new workrelated learning system is called workplace learning. The purpose of the new system is to assist the students in the acquisition of vocational knowledge and skills, and to facilitate their entry into labour market. In addition, current Finnish VET legislation requires that vocational schools cooperate with workplaces. It is hoped that in this way VET can respond better and quicker to the needs of working life.

The new workplace learning system in Finnish VET has been received very positively. For example, studies have shown, from pilot studies onwards, that vocational students have been motivated to learn "real work" during their workplace learning periods (Lasonen 2001). However, we have criticised the introduction of the workplace learning system as being based solely on reports from pilot studies, without consideration of recent literature or research on workplace learning (Virtanen \& Collin 2007). Thus, the aim of the present paper is to examine the recently reformed Finnish model of organising workplace learning for vocational students, looking at it from the point of view of research on learning at work. The study will compare the characteristics of workplace learning, (that is, what is learnt and how it is learnt) as it occurs among vocational students and among employees. The characteristics of employees' workplace learning are drawn from recent research on workplace learning, and they are incorporated within the theoretical part of this study. The empirical part of the study concerns the characteristics of students' workplace learning. We believe that our results can be utilised in other VET systems which are going through similar development processes. Our study can also provide ideas for the development of employees' workplace learning (see e.g. Billett 2000; 2001). 
Because our starting point is recent research on the characteristics of employees' workplace learning, we shall describe these characteristics briefly in the next section. After that we shall introduce the context of this study, the workplace learning system in Finnish VET, as laid out (in its ideal form) within the National Core Curriculum of VET. The empirical part of the article will begin with the description of the data and analytical methods used, and continue with our research results. Finally, we shall summarise our findings regarding the characteristics of students' workplace learning, and compare the students' learning with that of employees, setting out the similarities and differences.

\section{Characteristics of employees' workplace learning}

Studies of the complex field of workplace learning have proliferated in the last few decades (Eraut et al. 1998; Billett 2001; Engeström 2001; Gerber et al. 1995; Marsick and Watkins 1990; Wenger 1998). Despite the challenges it presents, it is possible to discern a certain measure of agreement about what characterises this field of inquiry. First, workplace learning is often described as informal, incidental and practice-bound, meaning that learning and work practices are difficult to separate from each other under the rapidly changing conditions of working life (see e.g. Lave 1993; Eraut 2004a; 2004b). Although workplace learning can be structured and include pedagogical practices (Billett 2004b; Fuller and Unwin 2002), much of this learning takes place informally as a side effect of work. When asking employees how they learn best in their job they usually emphasise in their answers the importance of actually doing the job (Collin 2002). Thus, learning is something which takes place while accomplishing everyday work-related tasks. A fundamental difference between learning in the workplace and learning in the school context therefore lies in the aim of the activity (Collin and Tynjälä 2003). In the workplace the aim is to get the job in question done and to be able to learn the kind of knowledge which can be utilised at work. This characteristic is, however, a very general one and hardly serves as a comprehensive picture of the phenomenon (Collin 2005). For this reason it is important to deepen our understanding of workplace learning by searching for other characterisations of this phenomenon.

A second characterisation concerns the importance of experience for learning (Beckett 2001; Boud and Miller 1996; Collin and Paloniemi 2008; Gerber 2001). The basis of workplace learning inheres largely in experience, that is, the ways in which people make sense of situations they encounter in their daily lives (Marsick and Watkins 1990; Weick 1995). Learning is embedded in everyday problem-solving situations (Bereiter and Scardamalia 1993), in the accumulation of competencies, in learning through mistakes (e.g. Bauer and Mulder 2007; Harteis et al. 2007) and in interactive negotiations with colleagues (Billett 2002). The basis of learning in the workplace is thus seen as the making of practical decisions and as the application of personal experience to the solving of specific problems or the performing of specific tasks, using intuition and common sense (Gerber 2001) and making sensible judgements (see also Beckett and Hager 2000). The most important things to be learnt through experiences are everyday interaction and co-operation with colleagues and other interested parties in and outside of the workplace, and acquiring a holistic picture of work processes and projects (see Boreham et al. 2002). Thus, learning can be characterised as the accumulation of experience and the employee's own ways of seeing what is important for their practice and learning (e.g. Collin 2004).

Third, working tasks and contexts determine what and how it is possible to learn at work (Brown et al. 1989; Fuller and Unwin 2004; Lave and Wenger 1991). Competence can neither be separated from the context in which the performance is expected to occur nor transferred from one context to 
another (Ellström 1997; Järvinen and Poikela 2001; Orr 1996). It has been widely recognised (e.g. Darrah 1996; Eraut 2002; Lave 1993; Wenger 1998) that in large part workplace learning is accomplished through participation in communities of practice (Billett 2004b) and is best understood by examining the relationship between practical work activities, the cultural and social relations of the workplace and the experience and social world of the participants (Evans and Rainbird 2002). Therefore the role of other people and networks also seem to be important for employees' learning at work. Thus, learning in the workplace may be characterised as shared. Learning usually seems to occur together with colleagues and various networks connected with individual worker's practices (Eteläpelto and Collin 2004; Gherardi 2001). As teamwork and networking become more widespread, more and more jobs come increasingly to involve social activities. Work often involves, in addition to cooperation with the immediate work community and team, collaboration with various groupings and networks outside the workplace (Tynjälä 2008a). Contemporary work practices are also described as temporary and situational and in a state of constant flux. Working goals and plans are redefined during processes and projects of all kinds. Problems and their solutions are also negotiated and constructed anew on each occasion in teams and groups. Therefore, most of our work today involves more discursive elements to jointly plan and organise the shared practices we are involved in (see Iedema and Scheeres 2003).

In sum, the studies reviewed above have shown that workplace learning can often be characterised as informal, experiential, context-bound and shared (see also Collin 2005). These features describe the nature of employees' workplace learning, that is, how employees learn at work. Employees' learning at work can be also considered as a content (what employees learn at work). For example, Eraut and his colleagues (2004b) have presented the following typology of what people learn at work: 1) task performance, including sub-categories such as speed and fluency, range of skills required and collaborative work; 2) awareness and understanding, involving understanding of colleagues, contexts and situations, one's own organisation, problems, risks, etc.; 3) personal development with aspects such as self evaluation and management, handling emotions, building and sustaining relationships, and the ability to learn from experience; 4) teamwork with subcategories such as collaborative work, and joint planning and problem solving; 5) role performance, including priorisation, leadership, supervisory role, delegation, crisis management etc.; 6) academic knowledge and skills, such as assessing formal knowledge, research-based practice, theoretical thinking and using knowledge sources; 7) decision making and problem solving, involving, for example, dealing with complexity, group decision making, and decision making under conditions of pressure; and 8) judgement, including quality of performance, output and outcomes, priorities, value issues and levels of risk. Eraut (2004b) notes that although presented as a typology, the authors view it more as a heuristic device for use in research and consultancy to remind people of possible aspects of learning present in their own context. These different learning outcomes described by Eraut and his colleagues can further be summarised into three basic categories which form the basis of vocational and professional expertise (see Tynjälä 2008b): 1) Conceptual and theoretical understanding (2 and 6 in Eraut's classification), 2) Practical skills or competences, including both domain-specific and more generic skills (1, 4, 5, 7, and 8), and 3) Self-regulative skills such as selfevaluation and management (3).

\section{Finnish vocational students as goal-oriented, guided and assessed learners in the workplace}

On the one hand, students' workplace learning is a part of formal vocational education in Finland. On other hand, it can also be regarded as (partly) informal learning which takes place outside the vocational schools, in authentic workplaces. In the new workplace learning system of Finnish VET, 
the general frameworks for organising workplace learning have been determined in the National Core Curriculum of VET. In fact, this model explicitly aims to formalise and structure students' learning in the workplace in order to promote their vocational learning and development. We shall now present workplace learning in its ideal form, as described in the National Curriculum Framework (Ammatillisen peruskoulutuksen opetussuunnitelman...2001).

Vocational qualifications take three years of full-time study, and all qualifications include at least 20 weeks of workplace learning. Thus, in this new workplace learning system, vocational students acquire at least one-sixth of their vocational qualification outside the vocational schools, in authentic workplaces. Students may seek out the workplace by themselves, but vocational schools can also help their students to find the placement. Before the beginning of the workplace learning period, the appropriateness of the workplace is to be evaluated by teachers in terms of students' opportunities for learning relevant skills, obtaining guidance, being provided with the required tools of the trade, and general sufficiency of production and service.

Usually, workplace learning is divided into two or more periods. In the early stage of vocational education workplace learning periods are often short, while later, when students have acquired more skills and knowledge, workplace learning can be extended and become more specific. Students are not just sent to the workplace to practise what they have learned at school, but the goals for every workplace learning period are derived from the curriculum, they are written up and all the parties involved in workplace learning (i.e. student, teacher and workplace trainer) are expected to be aware of them. The starting point is that the learning through participation in the work community alone may not be sufficient, as students may learn not only useful skills but also inappropriate attitudes and practices (e.g. Billett 2000). Therefore, a student's learning at work is guided by a workplace trainer, who, besides her/his own work duties, supports the students in the workplace, gives the students feedback and - ideally - supervises that the student's goals will be attained during the workplace learning period. Workplace learning is followed by an assessment discussion in which student, teacher and workplace trainer take part, and where it is ensured that the student has attained the goals which were set before the workplace learning period. The assessment discussion usually begins with the self-assessment by the student. Here, students evaluate their skills and knowledge against their learning goals. After this, the workplace trainer and the teacher give their assessments. Thus, the practice of workplace learning in Finnish VET is an endeavour to formalise and structure learning in an environment where much - but not all (Billett 2004a) - learning is usually informal (Eraut 2004a). In other words, Finnish vocational students' learning at work is goal-oriented and guided, and its outcomes are assessed.

\section{Aims, data, and methods of the study}

Our aim is to identify the characteristics of vocational students' workplace learning and compare them with the findings on employees' learning at work described above. More specifically, we address the following research questions: 1) What do students learn at work? 2) How do students learn at work? 3) Are there differences between the vocational fields in what and how students learn at work?, and 4) Does students' work experience and age have an impact on students' learning? 
In order to answer the research questions we collected data using the Internet and hard copy questionnaires; these were administered to Finnish VET students, teachers and workplace trainers ${ }^{1}$. The subjects of the study were all final year students of two large VET providers $(\mathrm{N}=3106)$ from six fields of Finnish VET: 1) technology and transport, 2) social services and health care, 3) commerce and administration, 4) tourism, catering and domestic services, 5) natural resources, and 6) culture. In total, 1603 students (52\%) answered the questionnaires. Students' average age was 21.35. In some cases, we also used views of students' workplace learning provided by teachers' and workplace trainers. The data from the teachers $(\mathrm{N}=796)$ were collected via an Internet questionnaire, and the data from the workplace trainers $(\mathrm{N}=2484$, out of which a random sample of 800 was taken) via an ordinary hard copy questionnaire. In total, 330 teachers ( $42 \%$ of all teachers) and 420 workplace trainers (53\% of the sample) answered the questionnaires. The teachers and the workplace trainers were drawn from the same six fields of VET. Most of the teachers and workplace trainers were 30-50 years old (teachers $57 \%$, workplace trainers $61 \%$ ). The over 50 year-old age group comprised $40 \%$ of the teachers and $28 \%$ of the workplace trainers. The under 30 -year-old age group comprised $3 \%$ of the teachers and $11 \%$ of the workplace trainers. In some cases, comparing the results between different fields of students, we have used data from the four biggest vocational fields of Finnish VET, which are 1) technology and transport, 2) social services and health care, 3) tourism, catering and domestic services, and 4) commerce and administration. These occupational fields differ greatly from each other. Machines and technological equipment have an essential role in the field of technology and transport, while social action and interaction between people dominate in the field of social services and health care. The field of technology and transport is the biggest and the widest vocational fields of Finnish VET, and it consists of the following subfields: mechanical, metal and energy engineering; electrical and automation engineering; automotive and transport engineering; and process, chemical and materials engineering. The field of tourism, catering and domestic services produces services for leisure time and welfare. In the field of commerce and administration the production of services is also emphasised, but involving different subfields, such as those of commerce, public administration and data processing.

To obtain answers to our first research question, What do students learn at work? we asked students to assess their learning outcomes as regards 29 different skills. These skills were drawn from (i) recent studies on the development of vocational competence, (ii) accounts on the skills requirements of working life, and (iii) skill descriptions within the National Core Curricula of VET (Commission of the European Communities 2005; Rychen and Salganik 2003; Tynjälä et al. 2006; Ammatillisen peruskoulutuksen opetussuunnitelman...2001). Because students from the different vocational fields had to be able to answer the same questions, there was no inquiry into field-specific vocational knowledge or skills. We also used an open-ended question, What students learnt in the workplace that they could not have learned at school? to get more versatile view of students' workplace learning. For our second research problem, we asked students questions derived from studies of workplace learning as a process (e.g. Billett 2001; 2002; Collin 2002; Fuller and Unwin 2004; Eraut 2002). These questions concerned topics such as how students learn at work, whom students learn from, and the role of previous work for students' workplace learning. For our third

\footnotetext{
${ }^{1}$ The Finnish educational system has three levels: 1) basic education, 2) upper secondary education and training (which is divided into a) general education and b) vocational education and training), and 3) higher education (which consists of two complementary sectors: the polytechnics and the universities). The nine-year basic education is compulsory for every Finnish citizen. After comprehensive school (basic education) almost all members of the relevant age (92\%) continue their studies in the upper secondary education and training (two thirds in general education and one third in vocational education and training). Both the general and the vocational sectors normally provide eligibility for further studies at universities and polytechnics. (Education and science in Finland 2006.)
} 
research question we compared mean values concerning student learning between different fields, and for the fourth question, we applied the two-way variance analysis to to test the relationship between students' prior work experience, age and the knowledge and skills they reported to having learnt during their workplace learning periods.

The data were analysed using quantitative methods (factor analysis to form aggregate scales, comparison of mean values, analyses of variance ANOVA, and two-way ANOVA). Effect sizes $\left(\eta^{2}\right)$ were calculated for the ANOVA analyses in which the values of .01, .06 and .14 were considered to be small, moderate and large, respectively (Coolican 2004, 491).

\section{Results}

\section{What did students learn at work?}

The students were asked to assess, on a five-point scale $(1=$ nothing, $2=$ some, $3=$ a fair amount, 4 $=$ a good deal, $5=$ a great deal) their learning outcomes as regards 29 different skills. In order to reveal the empirical structure of the construct, an exploratory factor analysis (PCA) was conducted. A KMO coefficient of .95 indicated good conditions for conducting factor analysis. On the basis of the factor analysis (a 6-component Varimax solution), we formed six aggregate scales describing students' learning outcomes during their workplace learning periods: 1) vocational skills, 2) collaboration skills, 3) independence, 4) communication skills, 5) learning skills, and 6) negative learning results (Table 1). The six components explain $64.57 \%$ of total variance. In addition, we use two single variables, self-assessment skills and thinking skills to describe students' learning outcomes. Table 1 shows 24 of 29 items. Five items (i.e. computer skills, occupational safety issues, trade union activities, planning of one's own career, and routine skills) were removed for theoretical and empirical reasons; they did not load for any scales meaningfully. Cronbach's alpha was used as reliability coefficient, and Table 1 shows that alpha for each of the aggregate scales was at least .60, which generally is the lowest acceptable value for forming a reliable aggrecate scale. Only variables that showed a correlation of at least .30 with the aggregate scale were accepted.

Table 1. Results of the factor analysis: six aggregate scales and two single variables describing the learning outcomes (n $=1547)$.

\begin{tabular}{|c|c|c|c|}
\hline Aggregate scale & $\begin{array}{l}\text { Cronbach's } \\
\text { alpha }\end{array}$ & $\begin{array}{l}\text { Items } \\
\text { (the maximum value cross-loading) }\end{array}$ & $\begin{array}{l}\text { Correlation of the } \\
\text { item with the } \\
\text { aggregate scale }\end{array}$ \\
\hline Vocational skills & 0.84 & $\begin{array}{l}\text { Planning and developing of one's work } \\
\text { Ability to solve occupation-related problems } \\
\text { Basic skills of one's own occupation } \\
\text { Having an overall picture of one's own field } \\
(0.80) \\
\text { Gaining workplace practices }\end{array}$ & $\begin{array}{l}0.70 \\
0.69 \\
0.69 \\
0.65 \\
0.50\end{array}$ \\
\hline Collaboration skills & 0.84 & $\begin{array}{l}\text { Collaboration skills }(0.756) \\
\text { Oral communication skills } \\
\text { Interaction skills } \\
\text { Teamwork skills }\end{array}$ & $\begin{array}{l}0.72 \\
0.71 \\
0.65 \\
0.65\end{array}$ \\
\hline Independence & 0.83 & $\begin{array}{l}\text { Self-confidence } \\
\text { Working independently (0.693) } \\
\text { Initiative }\end{array}$ & $\begin{array}{l}0.72 \\
0.68 \\
0.67\end{array}$ \\
\hline
\end{tabular}




\begin{tabular}{llll} 
Communication skills & 0.77 & Communication skills (0.757) & 0.69 \\
& & Presentation skills & 0.67 \\
& & Written communication skills & 0.51 \\
& & Using a foreign language in work & 0.43 \\
\hline Learning skills & 0.75 & Ability to operate in new situations (0.665) & 0.63 \\
& & Learning at work & 0.57 \\
& & Inventiveness and developing new ideas & 0.54 \\
\hline Negative learning outcomes & 0.73 & Bad practices & 0.62 \\
& & Shirking the duties & 0.59 \\
& & Disadvantages of one's own field (0.822) & 0.46 \\
\hline $\begin{array}{l}\text { Self-assessment skills } \\
\text { (single variable) }\end{array}$ & Assessing one's own work & \\
& & \\
\hline $\begin{array}{l}\text { Thinking skills } \\
\text { (single variable) }\end{array}$ & Critical thinking skills & \\
\hline
\end{tabular}

As can be seen from Table 2, the students reported that they had acquired a lot of different knowledge and skills during their workplace learning periods. The students felt that in particular they had learnt skills that involved independence, such as self-confidence, working independently, and initiative. The mean value of the aggregate scale for independence was 3.99 ( $\max 5)$. The students also reported that they had learnt vocational skills (mean value 3.84), learning skills (3.83), collaboration skills (3.82) and self-assessment skills (3.68). Most of the students also agreed that workplace learning was beneficial for learning thinking skills (3.22) and communication skills (3.00). In addition to these learning outcomes that were in line with the aims of workplace learning, the students reported that they had also learned some things at work that were undesirable, such as bad practices, shirking duties, and disadvantages of the field. These were labeled as negative learning outcomes. The mean value of the aggregate scale for negative learning outcomes was 2.13. (Table 2.) 
Table 2. Mean values of aggregate scales and single variables describing the learning outcomes (min 1 , max 5$)$ in different fields.

\begin{tabular}{|c|c|c|c|c|c|c|c|}
\hline Learning outcomes & $\begin{array}{l}\text { All students } \\
\mathrm{n}=1550 \\
\text { Mean value } \\
\text { (SD) }\end{array}$ & $\begin{array}{l}\text { Students of TT* } \\
\mathrm{n}=730 \\
\text { Mean value } \\
\text { (SD) }\end{array}$ & $\begin{array}{l}\text { Students of CA } \\
\mathrm{n}=147 \\
\text { Mean value } \\
\text { (SD) }\end{array}$ & $\begin{array}{l}\text { Students of TCDS } \\
n=147 \\
\text { Mean value } \\
\text { (SD) }\end{array}$ & $\begin{array}{l}\text { Students of SSHC } \\
\mathrm{n}=356 \\
\text { Mean value } \\
\text { (SD) }\end{array}$ & $\begin{array}{l}\text { Sig. of } \\
\text { differences } \\
\text { between } \\
\text { the fields }\end{array}$ & Effect size $\left(\eta^{2}\right)$ \\
\hline Independence & $\begin{array}{l}3.99 \\
(.79)\end{array}$ & $\begin{array}{l}3.82 \\
(.80)\end{array}$ & $\begin{array}{l}4.03 \\
(.81)\end{array}$ & $\begin{array}{l}4.06 \\
(.71)\end{array}$ & $\begin{array}{l}4.26 \\
(.72)\end{array}$ & $\mathrm{p}<0.001$ & 0.04 \\
\hline Vocational skills & $\begin{array}{l}3.84 \\
(.71)\end{array}$ & $\begin{array}{l}3.74 \\
(.70)\end{array}$ & $\begin{array}{l}3.68 \\
(.73)\end{array}$ & $\begin{array}{l}3.97 \\
(.67)\end{array}$ & $\begin{array}{l}4.07 \\
(.65)\end{array}$ & $\mathrm{p}<0.001$ & 0.05 \\
\hline Learning skills & $\begin{array}{l}3.83 \\
(.75)\end{array}$ & $\begin{array}{l}3.70 \\
(.76)\end{array}$ & $\begin{array}{l}3.84 \\
(.71)\end{array}$ & $\begin{array}{l}3.88 \\
(.73)\end{array}$ & $\begin{array}{l}4.07 \\
(.68)\end{array}$ & $\mathrm{p}<0.001$ & 0.04 \\
\hline Collaboration skills & $\begin{array}{l}3.82 \\
(.82)\end{array}$ & $\begin{array}{l}3.64 \\
(.81)\end{array}$ & $\begin{array}{l}3.77 \\
(.82)\end{array}$ & $\begin{array}{l}3.91 \\
(.75)\end{array}$ & $\begin{array}{l}4.19 \\
(.74)\end{array}$ & $\mathrm{p}<0.001$ & 0.08 \\
\hline Self-assessment skills & $\begin{array}{l}3.68 \\
(.96)\end{array}$ & $\begin{array}{l}3.53 \\
(.94)\end{array}$ & $\begin{array}{l}3.51 \\
(.96)\end{array}$ & $\begin{array}{l}3.63 \\
(.88)\end{array}$ & $\begin{array}{l}4.06 \\
(.91)\end{array}$ & $\mathrm{p}<0.001$ & 0.06 \\
\hline Thinking skills & $\begin{array}{l}3.22 \\
(1.06)\end{array}$ & $\begin{array}{l}3.07 \\
(1.07)\end{array}$ & $\begin{array}{l}3.19 \\
(1.07)\end{array}$ & $\begin{array}{l}3.22 \\
(.99)\end{array}$ & $\begin{array}{l}3.53 \\
(1.00)\end{array}$ & $\mathrm{p}<0.001$ & 0.03 \\
\hline Communication skills & $\begin{array}{l}3.00 \\
(.91)\end{array}$ & $\begin{array}{l}2.83 \\
(.91)\end{array}$ & $\begin{array}{l}3.08 \\
(.91)\end{array}$ & $\begin{array}{l}3.24 \\
(.93)\end{array}$ & $\begin{array}{l}3.22 \\
(.82)\end{array}$ & $\mathrm{p}<0.001$ & 0.04 \\
\hline Negative learning skills & $\begin{array}{l}2.13 \\
(.87)\end{array}$ & $\begin{array}{l}2.20 \\
(.91)\end{array}$ & $\begin{array}{l}2.02 \\
(.85)\end{array}$ & $\begin{array}{l}2.30 \\
(.93)\end{array}$ & $\begin{array}{l}1.94 \\
(.72)\end{array}$ & $\mathrm{p}<0.001$ & 0.02 \\
\hline
\end{tabular}

* Students of TT $=$ Students of technology and transport; Students of CA = Students of commerce and administration; Students of TCD = Students of tourism, catering, and domestic services; Students of SSHC = Students of social services and health care 
In all the learning outcomes the mean values differed highly significantly between four vocational fields: technology and transport, commerce and administration, tourism, catering, and domestic services, and social services and health care (Table 2). As regard to almost all asked knowledge and skills, the students from the field of social services and health care gave highest ratings. In fact, in the field of social services and health care, the mean values of the aggregate scales for independence, collaboration skills, vocational skills, learning skills, and self-assessment skills were above four. The social services and health care students, in turn, reported negative learning outcomes less frequently than the other students. Students from the field of tourism, catering and domestic services gave the highest scores for the learning of communication skills, and they also gave the second-highest ratings to all other positive learning outcomes. However, they also reported negative learning outcomes more than the students in other fields. The lowest ratings for vocational skills and self-assessment skills were given by the commerce and administration students, and the lowest ratings for independence, learning skills, collaboration skills, thinking skills and communication skills were given by the technology and transport students. (Table 2.) However, although the differences between the fields were all significant, the effect sizes were small or moderate (0.02-0.08). Because of the large sample, our tests of statistical significance are overpowered and results shall be interpreted in this light.

The students, teachers and workplace trainers were also asked to answer an open-ended question "What did you/students learn at the workplace that you/they could not have learned at school?" (Table 3). The answers fell into seven categories: workplace practices, technical skills, interaction skills, applying the theory, to get an overall picture of the field, responsibility for work duties, and other. Of those who answered the questionnaires this question was answered by $66 \%$ of the students, $81 \%$ of the teachers, and $91 \%$ of the workplace trainers.

Table 3. Students, teachers and workplace trainers answers to the question: What did students learn in the workplace that they could not have learned at school?

\begin{tabular}{|c|c|c|c|}
\hline $\begin{array}{l}\text { What did students learn at the } \\
\text { workplace that they could not have } \\
\text { learnt at school? }\end{array}$ & $\begin{array}{c}\mathrm{n}=1059 \\
\%\end{array}$ & $\begin{array}{l}\text { Teachers } \\
\mathrm{n}=267 \\
\%\end{array}$ & $\begin{array}{c}\text { Workplace } \\
\text { trainers } \\
\mathrm{n}=382 \\
\%\end{array}$ \\
\hline Workplace practices & 49 & 56 & 56 \\
\hline Technical skills & 19 & 7 & 3 \\
\hline Interaction skills & 17 & 17 & 25 \\
\hline Other & 9 & 1 & - \\
\hline Applying theory & 3 & 5 & 5 \\
\hline Gaining an overall picture of the field & 3 & 7 & 4 \\
\hline Responsibility for work duties & - & 7 & 7 \\
\hline
\end{tabular}

For all three respondent groups the most important learning for the student in the workplace was 'workplace practices' (Table 3). About $56 \%$ of each the workplace trainers and the teachers mentioned workplace practices as a learning outcome that could not be achieved at school and almost half of the students' answers referred to the same thing. The category 'workplace practices' consisted of phrases such as learning practical things, gaining practical experience, real work, and how work is actually done.

About one fifth of the students brought up the learning of technical skills - in general terms - as an important workplace learning outcome. The teachers and workplace trainers, however, did not mention the learning of technical skills so often but, instead, placed more emphasis on learning 
interaction skills. In sum, what the open-ended question adds to the description of learning outcomes given earlier is the more general view: in addition to the learning of specific skills the workplace provides students with a place to learn work practices.

\section{How did students learn at work?}

Students were asked to assess their different forms of learning on a three-point scale $(1=$ never, $2=$ sometimes, and $3=$ often). They had to assess how often they had learnt 'by being supervised by another person', 'by asking for advice', 'by working/doing things on their own', 'by working with someone else', 'by applying things that they had learned at school', 'through trial and error', and 'by talking with other people'. A KMO coefficient of .76 indicated good conditions for conducting factor analysis (PCA). On the basis of the results of the (exploratory) factor analysis we were able to form only one aggregated scale for these variables: social learning (Cronbach's alpha was .60 and the correlations of the items with the aggregate scale were over .30, Table 4). This component explains $33.74 \%$ of total variance. In addition to the aggregate scale for social learning, we used single variables: by working alone, by applying things learnt at school, and by trial and error. One item ("by talking with other people") was removed; it did not load for a formed scale meaningfully.

Table 4. Results of the factor analysis: aggregate scale and three single variables describing the forms of learning reported by students during their workplace learning periods $(n=1545)$.

\begin{tabular}{|c|c|c|c|}
\hline $\begin{array}{l}\text { Aggregate scale / } \\
\text { single variables }\end{array}$ & $\begin{array}{l}\text { Cronbach's } \\
\text { alpha }\end{array}$ & $\begin{array}{l}\text { Items } \\
\text { (the maximum value cross-loading) }\end{array}$ & $\begin{array}{l}\text { Correlation of the } \\
\text { item with the } \\
\text { aggregate scale }\end{array}$ \\
\hline Social learning & 0.60 & $\begin{array}{l}\text { By being supervised by other person } \\
\text { By asking for advice }(0.647) \\
\text { By working with someone else }\end{array}$ & $\begin{array}{l}0.47 \\
0.41 \\
0.35\end{array}$ \\
\hline $\begin{array}{l}\text { By working alone } \\
\text { (single variable) }\end{array}$ & & By working / doing things on her/him own & \\
\hline $\begin{array}{l}\text { By applying things learnt } \\
\text { at school } \\
\text { (single variable) }\end{array}$ & & $\begin{array}{l}\text { By applying things that student had learned } \\
\text { at school }\end{array}$ & \\
\hline $\begin{array}{l}\text { By trial and error } \\
\text { (single variable) }\end{array}$ & & Through trial and error & \\
\hline
\end{tabular}

Table 5 shows that the students felt that they had learnt at the workplace both by doing things on their own and together with their workplace trainer or other members of the work community. The mean value of learning by working alone was somewhat higher than that of social learning. Students also reported that they had learnt by applying things learnt at school or by trial and error. 
Table 5. Mean values of aggregate scale and three single variables describing the forms of learning of students during their workplace learning periods in different fields (min $1, \max 3)$

\begin{tabular}{|c|c|c|c|c|c|c|c|}
\hline $\begin{array}{l}\text { How did students } \\
\text { learn at work? }\end{array}$ & $\begin{array}{l}\text { All students } \\
\mathrm{n}=1545 \\
\text { Mean value } \\
\text { (SD) }\end{array}$ & $\begin{array}{l}\text { Students of TT* } \\
\mathrm{n}=722 \\
\text { Mean value } \\
\text { (SD) }\end{array}$ & $\begin{array}{l}\text { Students of CA } \\
\mathrm{n}=148 \\
\text { Mean value } \\
\text { (SD) }\end{array}$ & $\begin{array}{l}\text { Students of TCD } \\
\mathrm{n}=144 \\
\text { Mean value } \\
(\mathrm{SD})\end{array}$ & $\begin{array}{l}\text { Students of SSHC } \\
\mathrm{n}=359 \\
\text { Mean value } \\
\text { (SD) }\end{array}$ & $\begin{array}{l}\text { Sig. of } \\
\text { differences } \\
\text { between } \\
\text { the fields }\end{array}$ & Effect size $\left(\eta^{2}\right)$ \\
\hline By working alone & $\begin{array}{l}2.74 \\
(.46)\end{array}$ & $\begin{array}{l}2.65 \\
(.52)\end{array}$ & $\begin{array}{l}2.84 \\
(.36)\end{array}$ & $\begin{array}{l}2.82 \\
(.39)\end{array}$ & $\begin{array}{l}2.90 \\
(.29)\end{array}$ & $\mathrm{p}<0.001$ & 0.06 \\
\hline Social learning & $\begin{array}{l}2.49 \\
(.43)\end{array}$ & $\begin{array}{l}2.46 \\
(.44)\end{array}$ & $\begin{array}{l}2.45 \\
(.41)\end{array}$ & $\begin{array}{l}2.49 \\
(.42)\end{array}$ & $\begin{array}{l}2.61 \\
(.38)\end{array}$ & $\mathrm{p}<0.001$ & 0.02 \\
\hline $\begin{array}{l}\text { By applying things } \\
\text { learnt at school }\end{array}$ & $\begin{array}{l}2.25 \\
(.62)\end{array}$ & $\begin{array}{l}2.15 \\
(.63)\end{array}$ & $\begin{array}{l}2.12 \\
(.66)\end{array}$ & $\begin{array}{l}2.32 \\
(.57)\end{array}$ & $\begin{array}{l}2.47 \\
(.55)\end{array}$ & $\mathrm{p}<0.001$ & 0.05 \\
\hline By trial and error & $\begin{array}{l}2.00 \\
(.61)\end{array}$ & $\begin{array}{l}1.93 \\
(.60)\end{array}$ & $\begin{array}{l}2.12 \\
(.62)\end{array}$ & $\begin{array}{l}2.12 \\
(.62)\end{array}$ & $\begin{array}{l}2.06 \\
(.60)\end{array}$ & $\mathrm{p}<0.001$ & 0.02 \\
\hline
\end{tabular}

* Students of TT $=$ Students of technology and transport; Students of CA = Students of commerce and administration; Students of TCD = Students of tourism, catering, and domestic services; Students of SSHC $=$ Students of social services and health care 
Significant differences also emerged between the different vocational fields in the forms of learning (Table 5). The social services and health care students gave higher ratings for almost all the forms of learning than the students in the other fields. In particular, the mean value of social learning and also of learning by applying things learnt at school were clearly higher among the social services and health care students than those in the other fields. The technology and transport students gave the lowest ratings for learning by working alone and learning by trial and error, whereas the students of commerce and administration gave the lowest scores for social learning and learning by applying things learnt at school. Again, the effect sizes of the differences were small or moderate (0.02-0.06).

The extent of social learning by students (or the amount of their social contacts) were examined with a question in which they had to assesses how often they learnt during their workplace learning period from their workplace trainer, superior, some other employee, other workplace learner, or someone else (Table 6$)$. The scale was 1-3 $(1=$ never, $2=$ sometimes, and $3=$ often). Interestingly, the students reported having learnt at work most often from some other employee than from their workplace trainer. Students also reported having learnt at work from their superiors. 
Table 6. Persons students from different fields report having learnt from during their workplace learning periods (min 1, max 3)

\begin{tabular}{|c|c|c|c|c|c|c|c|}
\hline $\begin{array}{l}\text { Whom did students } \\
\text { learn from? }\end{array}$ & $\begin{array}{l}\text { All students } \\
\mathrm{n}=1550 \\
\text { Mean value } \\
\text { (SD) }\end{array}$ & $\begin{array}{l}\text { Students of TT* } \\
\mathrm{n}=730 \\
\text { Mean value } \\
\text { (SD) }\end{array}$ & $\begin{array}{l}\text { Students of CA } \\
\mathrm{n}=147 \\
\text { Mean value } \\
\text { (SD) }\end{array}$ & $\begin{array}{l}\text { Students of TCD } \\
\mathrm{n}=147 \\
\text { Mean value } \\
\text { (SD) }\end{array}$ & $\begin{array}{l}\text { Students of SSHC } \\
\mathrm{n}=356 \\
\text { Mean value } \\
\text { (SD) }\end{array}$ & $\begin{array}{l}\text { Sig. of } \\
\text { differences } \\
\text { between } \\
\text { the fields }\end{array}$ & Effect size $\left(\eta^{2}\right)$ \\
\hline Workplace trainer & $\begin{array}{l}2.44 \\
(.67)\end{array}$ & $\begin{array}{l}2.33 \\
(.70)\end{array}$ & $\begin{array}{l}2.40 \\
(.68)\end{array}$ & $\begin{array}{l}2.49 \\
(.64)\end{array}$ & $\begin{array}{l}2.68 \\
(.55)\end{array}$ & $\mathrm{p}<0.001$ & 0.05 \\
\hline $\begin{array}{l}\text { Some other } \\
\text { employee }\end{array}$ & $\begin{array}{l}2.52 \\
(.61)\end{array}$ & $\begin{array}{l}2.54 \\
(.61)\end{array}$ & $\begin{array}{l}2.41 \\
(.68)\end{array}$ & $\begin{array}{l}2.68 \\
(.51)\end{array}$ & $\begin{array}{l}2.50 \\
(.61)\end{array}$ & $\mathrm{p}<0.001$ & 0.01 \\
\hline Superior & $\begin{array}{l}1.99 \\
(.74)\end{array}$ & $\begin{array}{l}2.02 \\
(.72)\end{array}$ & $\begin{array}{l}2.18 \\
(.70)\end{array}$ & $\begin{array}{l}2.20 \\
(.71)\end{array}$ & $\begin{array}{l}1.73 \\
(.76)\end{array}$ & $\mathrm{p}<0.001$ & 0.05 \\
\hline Other workplace learners $* *$ & $\begin{array}{l}1.69 \\
(.66)\end{array}$ & $\begin{array}{l}1.59 \\
(.62)\end{array}$ & $\begin{array}{l}1.77 \\
(.69)\end{array}$ & $\begin{array}{l}1.87 \\
(.67)\end{array}$ & $\begin{array}{l}1.77 \\
(.65)\end{array}$ & $\mathrm{p}<0.001$ & 0.03 \\
\hline Someone else & $\begin{array}{l}1.47 \\
(.62)\end{array}$ & $\begin{array}{l}1.43 \\
(.60)\end{array}$ & $\begin{array}{l}1.40 \\
(.60)\end{array}$ & $\begin{array}{l}1.53 \\
(.61)\end{array}$ & $\begin{array}{l}1.54 \\
(.65)\end{array}$ & $\mathrm{p}=0.030$ & 0.01 \\
\hline
\end{tabular}

* Students of TT $=$ Students of technology and transport; Students of CA = Students of commerce and administration; Students of TCD = Students of tourism, catering, and domestic services; Students of SSHC = Students of social services and health care

** Where there was more than one workplace learner in the same workplace. 
Table 6 shows that there were differences between vocational fields. The role of the workplace trainer was accorded most importantly by students in the field of social services and health care, whereas the role of some other employee (than the workplace trainer) was emphasised in all the other fields, most often in tourism, catering and domestic services. The students from tourism, catering and domestic services also reported having learnt from their superiors more often than students in other fields. The effect sizes of the results were small (0.01-0.05) which must be taken into account in the interpretation of the results.

Although the students were rather young (mean age 21 years), $47 \%$ of them had already acquired experience $^{2}$ in their own fields (1-6 months $27 \%$ of students, $7-12$ months $10 \%, 1-2$ years $5 \%, 2-5$ years $3 \%$, over 5 years $2 \%$ ). The remaining $53 \%$ of students had no work experience. Work experience was categorised for the analyses into two categories: 'prior/practical experience' and 'no prior/practical experience'. As we assumed that students' age can be related to the amount of their work experience (i.e. the older the student, the more work experience), we used the two way analysis of variance (two-way ANOVA) to test the relationship between students' prior work experience, age and the knowledge and skills they reported to having learnt during their workplace learning periods. In this analysis, we used the variables described in Table 1. The results of the analysis of variance are shown on the left and the descriptive statistics related to students' work experience and age on the right side of Table 7.

\footnotetext{
${ }^{2}$ VET-related workplace learning periods were not counted as former experience, but part-time work was.
} 
Table 7. Results of variance analysis (two-way ANOVA): Relationship between students' prior work experience, age and knowledge and skills learned at work $(\mathrm{n}=1313)$

\begin{tabular}{|c|c|c|c|c|c|c|c|c|}
\hline \multirow{2}{*}{$\begin{array}{l}\text { Learning } \\
\text { outcomes }\end{array}$} & \multicolumn{3}{|c|}{ Age } & \multicolumn{2}{|c|}{ Work experience } & \multicolumn{3}{|c|}{ ANOVA F } \\
\hline & $\begin{array}{l}16-18 \\
M(S D)\end{array}$ & $\begin{array}{l}19-20 \\
M(S D)\end{array}$ & $\begin{array}{l}21-56 \\
M(S D)\end{array}$ & $\begin{array}{l}\text { No } \\
\mathrm{M}(\mathrm{SD})\end{array}$ & $\begin{array}{l}\text { Yes } \\
\text { M (SD) }\end{array}$ & Age, A (df) & Work experience, WE (df) & $A \times W E(d f)$ \\
\hline Independence & $3.91(.80)$ & $3.97(.74)$ & $4.07(.82)$ & $3.89(.78)$ & $4.08(.78)$ & $4.66^{* *}(2)^{\mathrm{a}}$ & $18.33 * * *(1)^{\mathrm{a}}$ & $0.44(2)$ \\
\hline Vocational skills & $3.79(.72)$ & $3.83(.69)$ & $3.92(.71)$ & $3.76(.71)$ & $3.93(.71)$ & $4.05^{*}(2)^{\mathrm{a}}$ & $19.19 * * *(1)^{\mathrm{a}}$ & $0.92(2)$ \\
\hline Learning skills & $3.76(.78)$ & $3.81(.73)$ & $3.89(.77)$ & $3.75(.76)$ & $3.89(.76)$ & $3.05^{*}(2)^{\mathrm{a}}$ & $12.40 * * *(1)^{\mathrm{a}}$ & $0.47(2)$ \\
\hline Collaboration skills & $3.75(.81)$ & $3.77(.80)$ & $3.92(.85)$ & $3.72(.82)$ & $3.91(.82)$ & $6.10 * *(2)^{\mathrm{a}}$ & $17.34 * * *(1)^{\mathrm{a}}$ & $1.02(2)$ \\
\hline Self-assessment skills & $3.55(.96)$ & $3.63(.94)$ & $3.85(.97)$ & $3.58(.99)$ & $3.77(.93)$ & $11.16^{* * *}(2)^{\mathrm{a}}$ & $13.68 * * *(1)^{\mathrm{a}}$ & $2.43(2)$ \\
\hline Thinking skills & $3.16(1.14)$ & $3.13(1.03)$ & $3.37(1.08)$ & $3.08(1.07)$ & $3.36(1.02)$ & $6.52 * *(2)^{\mathrm{a}}$ & $23.91 * * *(1)^{\mathrm{b}}$ & $0.14(2)$ \\
\hline Communication skills & $2.99(.90)$ & $2.98(.92)$ & $3.04(.92)$ & $2.89(.91)$ & $3.11(.91)$ & $0.67(2)$ & $19.11 * * *(1)^{\mathrm{a}}$ & $0.20(2)$ \\
\hline Negative learning outcomes & $2.28(.97)$ & $2.17(.92)$ & $2.01(.74)$ & $2.14(.90)$ & $2.16(.88)$ & $9.96^{* * *}(2)^{b}$ & $0.29(1)$ & $1.06(2)$ \\
\hline
\end{tabular}

\footnotetext{
${ }^{\mathrm{a}}$ Effect size $\left(\eta^{2}\right)=0.01$

${ }^{\mathrm{b}}$ Effect size $\left(\eta^{2}\right)=0.02$
} 
According to the results (on the left hand side of Table 7), there were no interaction effects between students' work experience and age as regards any knowledge or skills which they reported to have learnt at work. Instead, both work experience and age had a main effect on seven knowledge or skills. Students' prior work experience seemed to promote the development of all knowledge and skills ( $p<0.001)$ (excluding negative learning outcomes). Students' age seems to have an influence, in particular, on the development of self-assessment skills $(\mathrm{p}<0.001)$ and negative learning outcomes $(\mathrm{p}<0.001)$; the oldest students $(21-56)$ reported having learnt self-assessment skills most, and they felt having learnt negative things at work less than the younger students. Our results also suggest that students' age promotes the development of thinking skills $(\mathrm{p}=0.002)$, collaboration skills $(\mathrm{p}=0.002)$, independence $(\mathrm{p}=0.010)$, vocational skills $(\mathrm{p}=0.018)$, and learning skills $(\mathrm{p}=$ 0.048) (i.e. the oldest students reported more often than the younger ones having learnt these knowledge and skills). Instead, students' age did not seem to have an influence on the development of communication skills $(\mathrm{p}=0.513)$. However, results shall be interpreted suggestively, for the effect sizes were small (0.01-0.02) because of the large sample.

\section{Conclusions and discussion}

In this study, the characteristics of students' workplace learning were examined in the context of Finnish VET where every vocational student acquires at least one-sixth of her/his vocational qualifications in an authentic workplace. Students are not just sent off to work to practise what they have learned at school, but student's work experience is defined as goal-oriented, guided and assessed learning. We begin by summarising our findings of the characteristics of students' workplace learning and then we compare these results to the characteristics of employees' workplace learning as described in previous studies. When interpreting our findings it is important to keep in mind that there are some limitations in our study design. First, our methodological approach is mainly descriptive combined with exploratory use of statistical tests of quantitative data. Thus, the general design represents somewhat unorthodox approach to methodology. Second, the results are based on students' self-reported data rather than objective measures which may have an effect on the general credibility. Third, partly on the basis of the aspects pointed out above, the generalizability of the findings may be limited. However, we believe that findings give an overall view of students' workplace learning at least in the contexts where the study was carried out, that is, the Finnish VET and work environments.

According to our results, students' work experience is strongly learning-centred; students reported having learnt a lot of concrete knowledge and skills, such as independence, vocational skills, and learning skills, during their workplace learning periods, and they also reported having learnt workplace practices. However, not all learning results can be predefined, as the students also reported having learnt negative things in the workplace, such as bad practices. Second, the students reported that they had learnt at work both by doing themselves and working with others, the former somewhat more often. Third, there were differences between the different vocational fields in what and how they reported learning during their workplace learning periods. This would suggest that students' learning at work is field-specific. Fourth, students' former work experience seemed to promote their learning at work in some respects.

Next we compare the characteristics of students' and employees' workplace learning. This comparison is summarised in Table 8 where the features of employees' workplace learning have been drawn from the literature and the results of student learning at work from the present findings. 
Table 8. Summary of the features of employees' and students' workplace learning: what and how is learnt at work

\section{EMPLOYEES (former studies) STUDENTS (the present study)}

\begin{tabular}{lll}
\hline WHAT & 1) domain-specific and generic & 1) different general and vocational \\
practical skills and competences & skills and knowledge \\
2) conceptual and theoretical & 2) thinking skills \\
understanding & \\
3) self-regulative skills & 3) self-regulative skills \\
\end{tabular}

\begin{tabular}{lll}
\hline HOW & 1) mainly informally & 1) formally and informally \\
2) experientially & 2) experientially (in some respects) \\
3) context-boundly & 3) context-boundly and field-specifically \\
4) collaboratively & 4) by working alone and collaboratively
\end{tabular}

As can be seen from Table 8, employees' and students' learning in the workplace shows clear similarities but also differences. Below, we will examine these similarities and differences in more detail.

First, with respect to learning outcomes (i.e. what is learnt) the table shows that workplace learning, both for employees and for students, seems most often to produce improvement in the practical skills and competences needed in the job. This is hardly surprising since learning at work usually takes place while performing tasks which require these skills are used.

Second, earlier studies have shown that employees may also learn conceptual knowledge at work, but unfortunately our results do not allow us to state exactly to what extent students acquire conceptual and theoretical understanding during their workplace learning periods. This aspect as such was not included in our questionnaire. However, the questionnaire did contain an item about learning thinking skills, which is quite close to conceptual understanding. In our study the students' ratings of learning thinking skills were quite high, which leads us to assume that most students were able to enhance their conceptual understanding during their workplace learning periods. This is an important finding in view of the fact that many recent learning theories have emphasised the importance of the creation of the kind of learning environments that encourage students to conceptualise practical experience and particularise theoretical models and frameworks in workplace practices (see e.g. Guile and Griffiths 2001; Griffiths and Guile 2003; Tynjälä et al. 2006; Tynjälä 2008a). It is, in this way that work process knowledge develops (Boreham et al. 2002). In our earlier studies, we have found that such integration of theoretical and practical learning does occur in Finnish VET, although it varies widely in extent between different vocational fields (Virtanen and Tynjälä 2006; Virtanen and Tynjälä 2008).

Third, both employees and students seem to learn self-regulation while working. In our data the development of self-regulative skills was measured with the item on self-assessment skills. In fact, self-assessment is one of the main components of the structured and guided workplace learning programme described earlier in this article. Thus, it can be said that the development of selfregulation is one of the students' learning goals, and that the most students seem to achieve this goal (see also Stenström et al. 2006). 
Fourth, an important learning outcome that emerges from our student data is the learning of workplace practices, practical knowledge or just "practice", as students often call it. This is something that has been found to be manifested in a different way in the studies of employees' learning. Employees (at least the experienced ones) are already so familiar with the practices of their workplace that they feel no special need to learn them - unless new practices are introduced. Nevertheless, employees describe their learning process as practice-bound, that is, learning and doing the actual job cannot be separated (Collin 2005). Thus, for students workplace practice is a single learning goal and learning outcome (what is learnt), whereas for employees practices are related more to the way of learning (how something is learnt).

In Table 8, we also describe how students' learning at work takes place: 1) formally and informally, 2) experientially (in some respects), 3) in a situation that is context-bound and field-specific, and 4) by working alone and collaboratively. As compared to employees' learning we can make the following observations. First, while employees' workplace learning is mainly informal in nature, in students' learning features of both formal and informal learning were equally present. Students' experience of learning was strongly learning-centred not only because work experience was part of their vocational study programme but also because the learning itself was highly structured. For example, at the beginning of each workplace learning period students set their learning goals and wrote them down, and at the end of the period they assessed their learning together with their workplace trainers and teachers. Also, students were often assigned specific learning tasks or were encouraged to write learning journals throughout their workplace placement. All these formal structures were planned in order to enhance students' learning and make it more explicit.

Second, the role of experience and experiential learning, although evident in both employees and students, seems to be stronger among the former. Employees simply have more experience which they can use as a basis for interpreting and understanding new situations. We also found that students' former work experience may promote the development of certain skills and knowledge. This finding might have implications for student recruitment in VET. We can ask, for example, whether it would be feasible to give extra points for work experience in entrance examinations. If anything, students' previous work experience could be put to use and students encouraged to make use of it during their workplace learning periods. In addition, in workplaces more attention should be paid to the guidance of young students, because, according to our results, young students (they usually have also less prior work experience) seem to learn less different skills and knowledge at work and, first of all, they seem to learn more negative things than older students.

Third, nowadays it is generally acknowledged that all learning is situated in the context where it takes place. Among employees, this means that work tasks and the work environment determine what and how it is possible to learn at work. Of course the same applies to students' workplace learning as well. Furthermore, in our study we found not only that the conditions of the immediate work environment are important but also that the vocational field as a whole determines what and how students can learn at work. This may be self-evident in regard to field specific skills and knowledge, but in our study we focussed on generic skills and knowledge needed in all fields. We found differences between the fields in this respect. For example, students in social services and health care gave the highest ratings in almost all the different learning outcomes. Students from different fields also differed in how they learnt at work. Again, social services and health care students' ratings of different forms of learning (e.g. social learning, learning by applying things learnt at school) were higher than those of students in other fields. These findings suggest that different VET-related workplace learning cultures hold sway in different fields (see Virtanen et al. 2008); if so, we can describe students' workplace learning as field-specific. This finding is 
somewhat alarming, since it suggests that different vocational fields seem to offer for their students different possibilities to learn at work. It is important to keep in mind, however, that because of the large sample sizes the tests of statistical significances between different vocational fields were slightly overpowered: the effect sizes were mostly small or moderate. Even so, it would be important in future studies to analyse and clarify the causes of these differences. Only in this way can VET practices of workplace learning be developed so as to guarantee equal opportunities for learning in all fields. It would be important also to pay attention to differences in working and learning cultures between different occupational fields in employees' learning at work, as this research topic has been almost totally neglected in workplace learning research.

Fourth, while studies of employees' learning at work consistently emphasise the role of collaboration, interaction and shared practices in learning, the students in our study reported learning more often by working alone than by working with others. One explanation for this may be the fact that for students their main aim is to acquire the basic vocational skills and knowledge they need for their vocational qualifications and that this motivates students to individual ambitions. On the other hand, it may be that students do not recognise or perceive learning as a shared activity in the workplace. Although students reported that they had learnt more by working alone than by working together with others, their number of social contacts was quite high: they reported having learnt from workplace trainers, other employees, superiors, other workplace learners or other people. This finding suggests that students' learning at work is perhaps more social or shared in nature than students themselves recognise. It is also possible that in the workplace, due to urgent business, students are assigned the kind of tasks that do not make heavy demands on the presence of and supervision by more experienced workers. Also students' young age may operate as a constraint on doing or learning together with others. For instance, some workplace trainers stated that sometimes a student's shyness, possibly related her/his young age, acted as a constraint in customer service work (Virtanen and Collin 2007).

Taken as a whole, all the features typical of employees' learning at work can be found in students' learning at work as well. However, VET-related workplace learning, at least in the Finnish system, has some characteristics that have not emerged in research on employees' workplace learning up till now. For students, workplace learning is formalised and structured, which means that learning at work is goal-oriented, guided and assessed. Various kinds of formalisms and structures can equally be present in workplace practices for employees (Billett 2004b), but in most studies employees' learning is described as informal and incidental learning. We would assume that the structured workplace learning system in place in Finnish VET is conducive to good learning outcomes and it has also helped students to be aware of their learning at work. Thus, the new system seems to be successful in this respect, a finding that runs counter to our previous concern about the minimal utilisation of recent research on workplace learning in the development of the new VET workplace learning system (see Virtanen and Collin 2007). Indeed, we would suggest that formalising and structuring the learning of employees in the workplace could, to some extent, make a difference in human resources development. In this sense, the principles of Finnish VET workplace learning system for students could be usefully applied. The implication is that employees could set explicit learning goals, that employees' learning at work could be guided by experienced colleagues, and that after a certain time, the accomplishment of the learning goals could be assessed by the learner and his/her guide. These kinds of structures and formalisms of workplace learning could be connected, for example, with a mentoring or peer group mentoring system (see Heikkinen et al. 2008). On the other hand, we would also suggest that school-based learning and VET-related workplace learning has something to learn from employees' learning, in making more use of collaboration and shared practices. Our study indicates that this would be particularly important in the guidance of younger students. It seems that the old culture of individual learning is still strongly 
present in the formal education system, whereas social skills and knowledge-sharing are needed in "real life". In sum, for developing educational practices it would be useful to adopt some of the features of employees' workplace learning, and for developing workplace practices it would be useful to adopt some of the features of formal educational practices.

ACKNOWLEDGEMENT: The research presented in this paper was partly supported by a grant from the Academy of Finland (Project no. 111184).

\section{References}

Ammatillisen peruskoulutuksen opetussuunnitelman ja näyttötutkinnon perusteet. (2001). [National core curriculum of the initial vocational education and competence-based qualifications.] Sosiaalija terveysalan tutkinto. Helsinki: Opetushallitus.

Bauer, J., \& Mulder, R. (2007). Modelling learning from errors in daily work. Learning in Health and Social Care 6(3), 121-133.

Beckett, D. (2001). Hot action at work: a different understanding of "understanding". In T. Fenwick (Ed.) Sociocultural perspectives on learning at work (pp. 73-83). New York: Jossey-Bass.

Beckett, D., \& Hager, P. (2000). Making judgements as the basis for workplace learning: towards an epistemology of practice. International Journal of Lifelong Learning 19(4), 300-311.

Bereiter, C., \& Scardamalia, M. (1993). Surpassing ourselves: an inquiry into the nature of expertise. Chicago: Open Court.

Billett, S. (2000). Guided learning at work. Journal of Workplace Learning 12(7), 272-285.

Billett, S. (2001). Learning in the workplace. Strategies for effective practice. Crows Nest: Allen \& Unwin.

Billett, S. (2002). Workplace pedagogic practices: Co-participation and learning. British Journal of Educational Studies 50(4), 457-481.

Billett, S. (2004a). Learning through work. Workplace pedagogical practices. In H. Rainbird, A. Fuller \& A. Munro (Eds.) Workplace learning in context (pp. 109-125). London: Routledge.

Billett, S. (2004b). Workplace participatory practices. Conceptualising workplaces as learning environments. The Journal of Workplace Learning 16(6), 312-324

Boreham, N., Samurcay, R., \& Fisher, M. (Eds.) (2002). Work process knowledge. London: Routledge.

Boud, D., \& Miller, N. (1996). Synthesising traditions and identifying themes in learning from experience. In D. Boud \& N. Miller (Eds.) Working with experience (pp. 9-18). London: Routledge.

Brown, J. S., Collins, A., \& Duguid, P. (1989). Situated cognition and the culture of learning. Educational Researcher 18(1), 32-42. 
Collin, K. (2002). Development engineers' conceptions of learning at work. Studies in Continuing Education 24(2), 133-152.

Collin, K. (2004). The role of experience in work and learning among design engineers. International Journal of Training and Development 8(2), 111-127.

Collin, K. (2005). Experience and shared practice. Design engineers' learning at work. Jyväskylä: University of Jyväskylä. Doctoral dissertation.

Collin, K., \& Tynjälä, P. (2003). Integrating theory and practice? Employees' and students' experiences of learning at work. Journal of Workplace Learning 15(7/8), 338-344.

Collin, K., \& Paloniemi S. (2008). Supporting experience sharing as participatory workplace practice. In S. Billett, C. Harteis \& A. Eteläpelto (Eds.) Emerging Perspectives of Workplace Learning (pp.167-181). Rotterdam: Sense Publishers.

Commission of the European Communities. (2005). Towards a European Qualifications Framework for lifelong learning. Commission staff working document. Brussels 8.7. 2005.

Coolican, H. (2004). Research methods and statistics in psychology. Fourth edition. London: Hodder \& Stoughton.

Darrah, C. (1996). Learning at work: An exploration in industrial ethnography. London: Garland Publishing.

Education and science in Finland. (2006). Ministry of Education publications 2006: 15. Retrieved October 23, 2008, from http://www.minedu.fi/export/sites/default/OPM/Julkaisut/2006/liitteet/eng_opm15.pdf?lang=en

Ellström, P.-E. (1997). Many meaning of occupational competence and qualification. In A. Brown (Ed.) Promoting vocational educationa and training: European perspectives (pp. 47-58) Hämeenlinnan opettajankoulutuslaitos. Ammattikasvatussarja 17.

Engeström, Y. (2001). Expansive learning at work: toward an activity theoretical reconceptualization. Journal of Education and Work 14(1), 133-156.

Eraut, M. (2002). The interaction between qualifications and work-based learning. In K. Evans, P. Hodkinson, \& L. Unwin (Eds.) Working to learn - Transforming learning in the workplace (pp. 6378). London: Kogan Page.

Eraut, M. (2004a). Informal learning in the workplace. Studies in Continuing Education 26(2), 247273.

Eraut, M. (2004b). Transfer of knowledge between education and workplace settings. In H.Rainbird, A. Fuller, \& A. Munro (Eds.) Workplace learning in context (pp. 201-221). London: Routledge.

Eraut, M., Alderton, J., Cole, G., \& Senker, P. (1998). Development of knowledge and skills in employment. Final report of a research project funded by "The Learning Society" Programme of the Economic and Social Research Council. University of Sussex. 
Eteläpelto, A., \& Collin, K. (2004). From individual cognition to communities of practice. In H. P. A. Boshuizen, R. Bromme, \& H. Gruber (Eds.) Professional learning: Gaps and transitions on the way from novice to expert (pp. 231-250). Dordrecht: Kluwer Academic Publishers.

Evans, K., \& Rainbird, H. (2002). The significance of workplace learning for a 'learning society'. In K. Evans, P. Hodkinson, \& L. Unwin (Eds.) Working to learn - Transforming learning in the workplace (pp. 7-28). London: Kogan Page.

Fuller, A., \& Unwin, L. (2004). Expansive learning environments. Integrating organizational and personal development. In H. Rainbird, A. Fuller \& A. Munro (Eds.) Workplace learning in context (pp. 126-144). London: Routledge.

Fuller, A., \& Unwin, L. (2002). Developing pedagogies for the contemporary workplace. In K. Evans, P. Hodkinson \& L. Unwin (Eds). Working to learn. Transforming learning in the workplace (pp. 95-111). London: Kogan Page.

Gerber, R. (2001). The concept of common sense in workplace learning and experience. Education and Training 43(2), 72-81.

Gerber, R., Lankshear, C., Larsson, S., \& Svensson, L. (1995). Self-directed learning in work context. Education + Training 37(8), 26-32.

Gherardi, S. (2001). From organizational learning to practice-based knowing. Human Relations 54(1), 131-139.

Griffiths, T., \& Guile, D. (2003). A connective model of learning: the implications for work process knowledge. European Educational Research Journal 2(1), 56-73.

Guile, D., \& Griffiths, T. (2001). Learning through work experience. Journal of Education and Work 14(1), 113-131.

Harteis, C., Bauer, J., \& Haltia, P. (2007). Learning from errors in the workplace - Insights from two studies in Germany and Finland. In H.Gruber \& T. Palonen (Eds.) Learning in the workplace new developments (pp.119-138). Turku: Painosalama Oy.

Heikkinen, H., Jokinen, H., \& Tynjälä, P. (2008). Reconceptualising mentoring as a dialogue. In G. Fransson, \& C. Gustafsson (Eds.) Newly qualified teachers in Northern Europe. University of Gävle. Teacher Education: Research Publications 4, 107-124.

Iedema, R., \& Scheeres, H. (2003). From doing work to talking work: Renegotiating knowing, doing and identity. Applied Linguistics 24(3), 316-337.

Järvinen, A., \& Poikela, E. 2001. Modelling reflective and contextual learning at work. Journal of Workplace Learning 13(7/8), 282-289.

Lasonen, J. (2001). Työpaikat oppimisympäristöinä: työpaikkajohtajien, opiskelijoiden, työpaikkaohjaajien ja opettajien arviot Silta-hankkeen $(2+1)$ kokeilun kokemuksista. [Workplaces as learning environments. Impact of on-the-job training on networking and students' learning in the Bridge project (2+1 Experiment).] Helsinki: Opetushallitus. 
Lave, J. (1993). The practice of learning. In S. Chaiklin, \& J. Lave (Eds.) Understanding practice. Perspectives on activity and context (pp. 3-34). Cambridge University Press.

Lave, J., \& Wenger, E. (1991). Situated learning. Legimate peripherial participation. Cambridge: Cambridge University Press.

Marsick, V. J., \& Watkins, K. E. (1990). Informal and incidental learning in the workplace. London: Routledge.

Orr, J. E. (1996). Talking about machines. An ethnography of a modern job. Ithaca, NY: IRL Press/Cornell University Press.

Rychen, D.S., \& Salganik, L.H. (Eds). (2003). Key competencies for successful life and wellfunctioning society. Cambridge, MA: Hogrefe \& Huber.

Stenström, M.-L., Laine, K., \& Kurvonen, L. (2006). Practice-oriented assessment - towards quality assurance through vocational skills demonstrations. In M-L. Stenström \& K. Laine (Eds.), Quality and practice in assessment. New approaches in work-related learning (pp. 89-120). University of Jyväskylä. Institute for Educational Research.

Streumer, J. N., \& Kho, M. (2006). The world of work-related learning. In J. N. Streumer (Ed.), Workrelated learning (pp. 3-49). Dordrecht: Springer.

Tynjälä, P. (2008a). Perspectives into learning at the workplace. Educational Research Review 3, $130-154$.

Tynjälä, P. (2008b). Connectivity and transformation in work-related learning: Theoretical foundations. In M-L. Stenström, \& P. Tynjälä (Eds.) Towards integration of work and learning: Strategies for connectivity and transformation. Dordrecht: Springer (in press).

Tynjälä, P., Slotte, V., Nieminen, J., Lonka, K., \& Olkinuora, E. (2006). From university to working life: Graduates' workplace skills in practice. In P. Tynjälä, J. Välimaa, \& G. BoultonLewis (Eds), Higher education and working life: Collaborations, confrontations and challenges (pp. 73-88). Amsterdam: Elsevier.

Virtanen, A., \& Collin, K. (2007). Työssäoppiminen ammatillisessa peruskoulutuksessa. [Workplace learning in Finnish VET.] In A. Eteläpelto, K. Collin, \& J. Saarinen (Eds.) Työ, oppiminen ja identiteetti (pp. 216-235). Helsinki: WSOY.

Virtanen, A., \& Tynjälä, P. (2008). Students' experiences of workplace learning in Finnish VET. European Journal of Vocational Training 44, 199-213.

Virtanen, A., \& Tynjälä, P. (2006, October). Workplace learning in Finnish VET - Students', teachers' and workplace trainers' perspectives. Paper presented at the EARLI SIG Professional Learning and Development Conference, Heerlen, the Netherlands.

Virtanen, A., Tynjälä, P., \& Stenström, M-L. (2008). Field-specific educational practices as a source for students' vocational identity formation. In S. Billett, C. Harteis, \& A. Eteläpelto (Eds.) Emerging Perspectives of Workplace Learning (pp. 19-34). Rotterdam: Sense Publishers. 
Weick, K. E. (1995). Sensemaking in organisations. London: SAGE.

Wenger, E. (1998). Communities of practice. Learning, meaning and identity. Cambridge: CUP. 